\title{
Introduction: Law Between Two Vertigos
}

\author{
Kyle McGee ${ }^{1}$
}

Published online: 17 May 2017

(C) Springer Science+Business Media Dordrecht 2017

On 28 March 2017 President Trump took the first major step in obliterating U.S. climate policy by signing an executive order peeled directly from the wish list of the Heartland Institute and the American Petroleum Institute. In its wake, federal lands are being opened up to leasing for coal mining, all regulations and agency actions that may 'potentially burden' the development of domestic energy resources are to be subjected to comprehensive 'review' and offending rules must be 'suspend[ed], revise[d], or rescind[ed]' on an aggressive schedule, and multitudes of emission and extraction policies, limits, and standards have been or will soon be revoked. This is not business-as-usual; the order is not a mere visible hand lightly correcting the energy markets, but a massive, concentrated intervention in the climate struggle.

This order is a fitting reminder that the despotic overcoding of law has its anchor not only in the marriage of neoliberalism and nationalism but also deep in a geocidal political ecology. These harbours offer, in their perverse way, refuge, security, and sanity to those exhausted by globalization and overwhelmed by the calamity of global warming: the bedrock of national identity and national borders, grounded firmly in the stability of a universal, endless, permanent nature. These are unmistakable responses to the economic vertigo of placelessness and the ecological vertigo of landlessness; ports of call in a turbulent sea bridged by a vulgar, instrumental, topsy-turvy vision of legality trading only too readily on the conceits of liberal legal theory and the Obama administration's prerogative state apparatus.

There is admittedly a risk in scrutinizing Trumpism-and even in naming itwhile it remains in its putative youthful ascendancy (putting aside that, at its core, it is already moribund, dead on arrival) before it has had an opportunity to leave us a 'toxic legacy' (Moncrieff). But this risk is in truth an obligation, because the electoral campaign's shots across the bow and the post-election utterances, policy

Kyle McGee

kylemcgee@gmail.com

1 PO Box 2174, West Chester, PA 19380, USA 
positions, and cabinet appointments already disclosed that Trumpism means waron meaning, legitimacy, and truth; on workers, migrants, refugees, the undocumented; on women; on nonwhites; on Muslims; on the poor; and on the earth.

The immediate occasion for this Supplement on 'Trumpism, Law, and Political Ecology' is the publication of my Heathen Earth: Trumpism and Political Ecology (2017), an intentionally premature study of the political-legal constitution of this moment, and what follows are responses, speculations, provocations, and perambulations on some of its priorities. This collaboration offers the authors an opportunity to collect the perplexities associated with the current nationalist retreat, in the U.S. and beyond, and subject them to critical scrutiny. To that end, Philip Conway measures the geopolitical stakes of global warming in a scathing take on Trumpist nihilism; Kari de Pryck and François Gemenne offer a sober, sobering snapshot of the recent history of climate denialism in light of Trumpism, situating the 'denier-in-chief' in a more complicated story; Lilian Moncrieff detects signs of the sludgy, plasmatic worlds-between-worlds hovering menacingly in the background, in the dark causalities now coming into the light of officialdom; and Stephen Muecke moves among other voids, tracing an experimental jurisprudence of institutions from three scenes drawing together Indigenous law, colonial ecoviolence, and their abstract mediators.

\section{Reference}

McGee, Kyle. 2017. Heathen earth: Trumpism and political ecology. Earth, Milky Way: Punctum Books. 